Suppl. Fig. S2A

Chromosome 21

Insertions $10-100$ bp
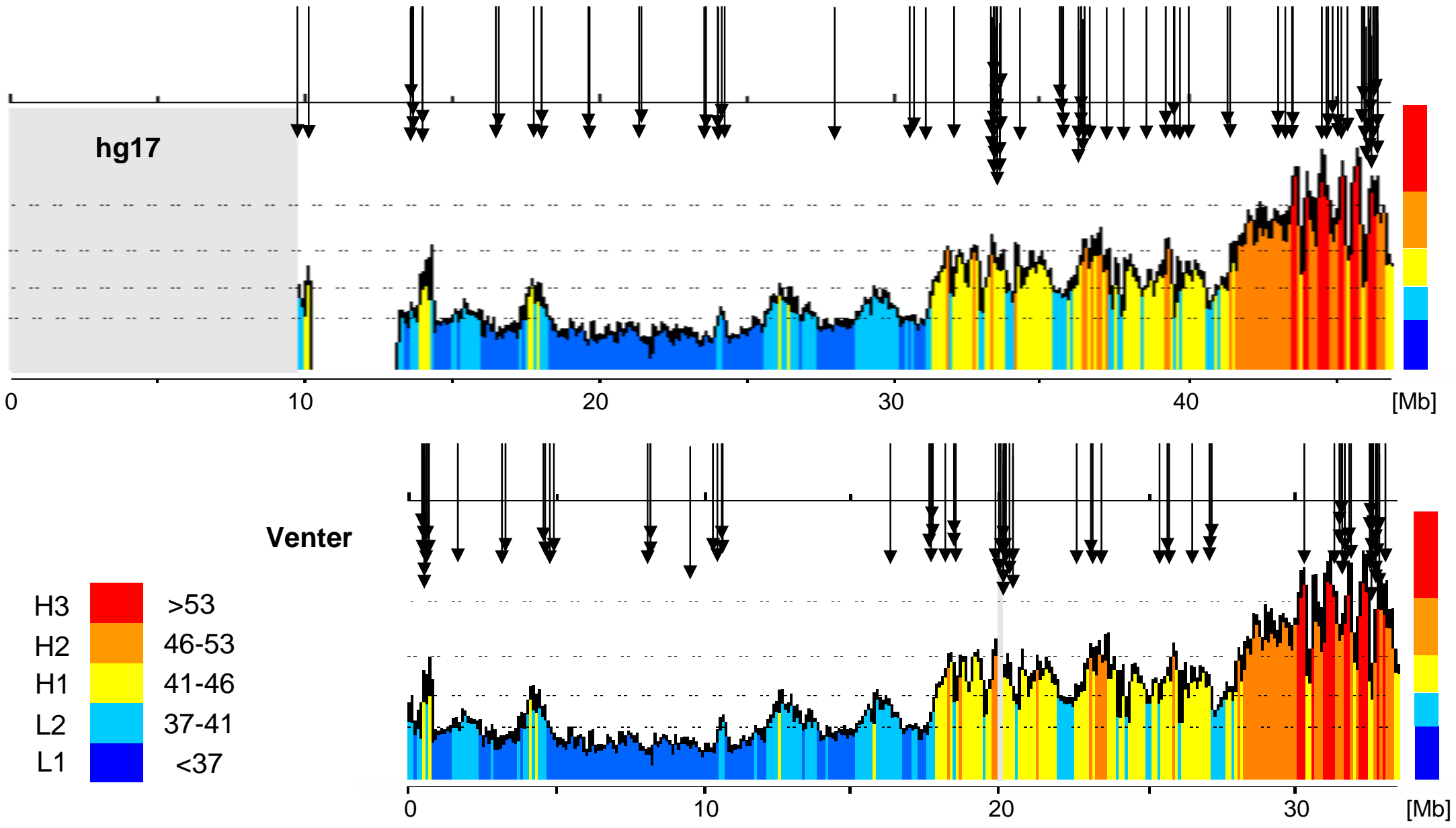
Suppl. Fig. S2B

\section{Chromosome 21}

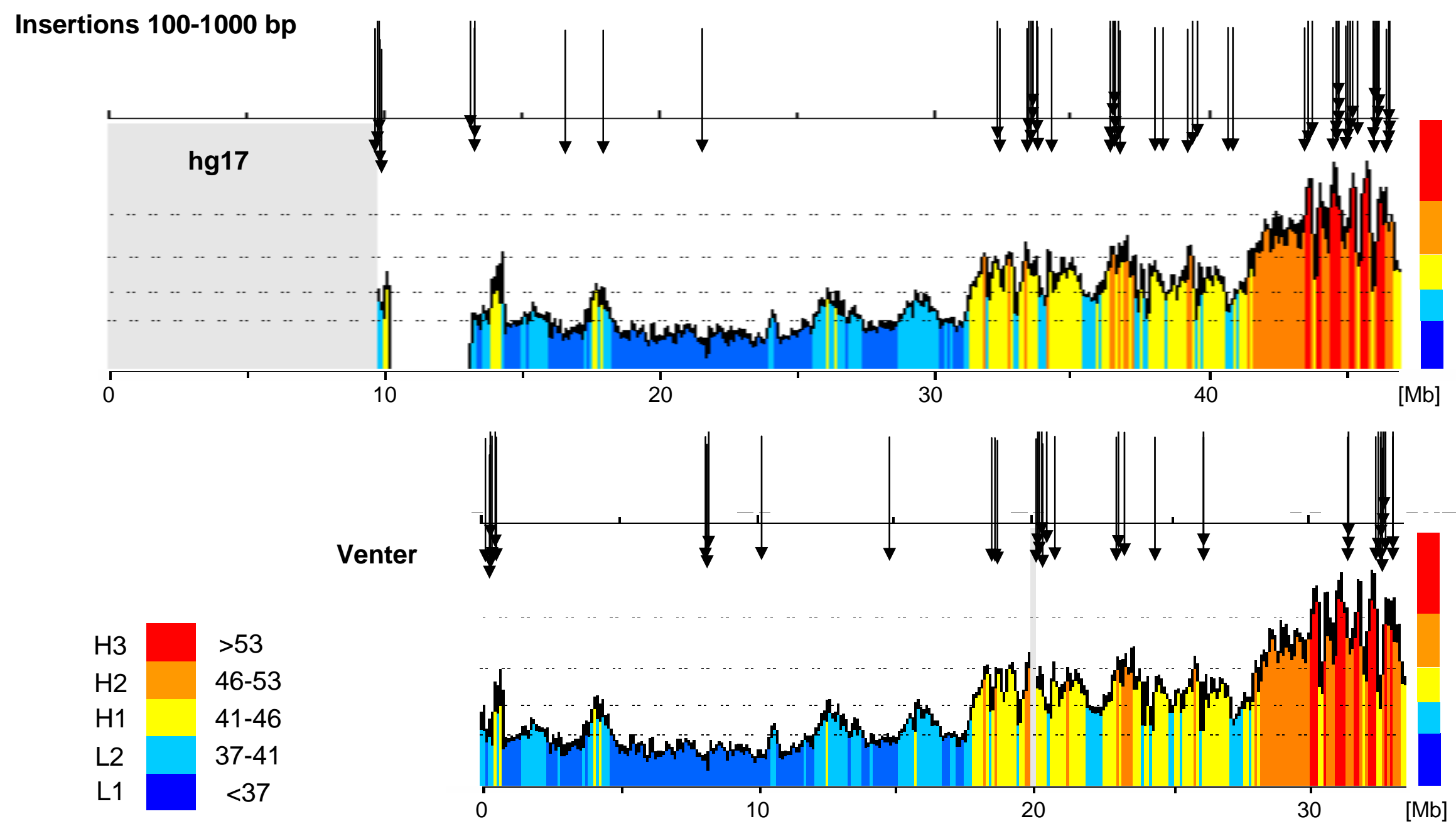

